\title{
Law-Making by Human Rights Treaty Bodies
}

Geir Ulfstein

\section{Introduction}

Treaty bodies are used in different parts of international law: international arms control, international environmental law and international human rights. What they have in common is that they are established by treaties but they are neither formal international organisations nor international courts. They may exercise different kinds of functions, including law-making, supervision and dispute settlement.

International human rights are special in the sense that, rather than being of a reciprocal inter-state character, they apply to the relationship between individuals and the state while being a common global concern. This special character is reflected in a combination of an individual and a collective approach to their supervision. First, both regional human rights courts and treaty bodies deal with individual complaints, i.e. an individual approach. Second, the treaty bodies examine reports from states, i.e. a collective approach. The treaty bodies also adopt General Comments based on their case law. ${ }^{1}$

All of these activities may be seen as law-making in a wider sense: the treaty bodies determine the precise scope of the vague obligations in the relevant conventions - including through their dynamic ('evolutive') interpretation. This is done on an individual basis in cases of individual complaints - comparable to the functions of courts. The examination of state reports assesses the implementation of international obligations and thus also has legal - and possibly law-making elements, albeit of a more administrative character. The adoption of General Comments resembles legislation, i.e. law-making in the proper sense, by setting out general guidelines for the interpretation of the treaty obligations.

In this chapter I will examine the legal basis for the different functions of the treaty bodies. I will also address to what extent the treaty bodies should act as legal organs or policy organs. With respect to their legal function, it is also relevant to discuss how far the treaty bodies should go in their law-making - given that they their formal role is that of dispute settlement and supervision of implementation.

\footnotetext{
${ }^{1}$ I will not deal with the power to conduct special investigations. Only two human rights bodies have such a power, see Convention against Torture and Other Cruel, Inhuman or Degrading Treatment or Punishment, GA Res. 39/46, 10 December 1984, in force 26 June 1987, 1465 UNTS 85, Article 20; Convention on the Elimination of All Forms of Discrimination against Women, GA Res. 34/180, 18 December 1979, in force 3 September 1981, 1249 UNTS 13, Article 8. The power to receive inter-state complaints has never been used in practice.
} 
The treaty bodies must ensure that human rights are effectively protected through their interpretation. But, given that their findings have a 'soft law' character, they should also have an eye on methods of interpretation that will persuade national constitutional organs, including domestic courts. Finally, in the current treaty body strengthening process, ${ }^{2}$ they may need the political support of states. I will focus on law-making by the UN human rights treaty bodies, especially the Human Rights Committee. ${ }^{3}$

\section{Examination of state reports}

While the International Covenant on Civil and Political Rights (ICCPR) entered into force in 1976, ${ }^{4}$ it was not until the end of the Cold War that its supervisory body, the Human Rights Committee (HRC), could exercise its general functions in examining state reports and adopting General Comments. The reasons are partly political and partly legal. In terms of the legal issues, Article 40 of the Covenant establishes:

1. The States Parties to the present Covenant undertake to submit reports on the measures they have adopted which give effect to the rights recognized herein and on the progress made in the enjoyment of those rights ....

4. The Committee shall study the reports submitted by the States Parties to the present Covenant. It shall transmit its reports, and such general comments as it may consider appropriate, to the States Parties. The Committee may also transmit to the Economic and Social Council these comments along with the copies of the reports it has received form States Parties to the present Covenant.

As will be seen, this article does neither make it clear that the Committee's reports and its General Comments are two different supervisory functions nor what the content of its reports and its General Comments may be.

During the Cold War, the Committee members from the communist countries emphasized the need for a 'constructive dialogue' and the Committee did not adopt any Concluding Observations about the relevant state's implementation of its human rights obligations. It was only after the end of the Cold War, in 1992, that

\footnotetext{
${ }^{2}$ See Office of the United Nations High Commissioner for Human Rights 'The Treaty Body Strengthening Process', <www2.ohchr.org/english/bodies/HRTD/index.htm>.

${ }^{3}$ In preparing this chapter I have benefited from the work on the book Helen Keller and Geir Ulfstein (eds), UN Human Rights Treaty Bodies: Law and Legitimacy (Cambridge University Press, 2012).

${ }^{4}$ International Covenant on Civil and Political Rights, UNGA Res 2200A (XXI), 16 December 1966, in force 23 March 1976, 999 UNTS 171.
} 
the Committee commenced its adoption of Concluding Observations on the basis of examination of state reports and its oral examination. ${ }^{5}$

It would seem beyond doubt that the HRC - and the other treaty bodies entrusted with examination of state reports - has the competence to adopt Concluding Observations on states' implementation of their international obligations on the basis of state reports. The question is how this function should be exercised and, in our context, whether the treaty bodies' recommendations should have a legal or a policy character. 6

The treaty bodies should clearly comment on the legal aspects of the relevant state's implementation of its obligations. This requires that the treaty body has a composition with sufficient legal credibility. It is also wise to phrase the findings as 'concerns' - as is the practice of the HRC - rather than to determine whether the international obligations have been violated. Such determinations are generally more appropriate in dealing with individual cases.

However, the treaty bodies have not shied away from giving policy recommendations. This would also seem to be acceptable and advisable. But their activity in providing policy advice should reflect their composition: lawyers are not necessarily policy experts. Furthermore, the concreteness of the treaty bodies' advice should depend on their knowledge both about the factual situation in the relevant country and its political and cultural traditions. The treaty bodies should leave enough room for the national policy-making organs and not impose specific solutions on a country if the international obligations leave room for policy choices, bearing in mind that international human rights obligations generally give directions concerning result, not the means to be applied. Finally, the advice should be sufficiently connected to the obligations contained in the relevant convention.

\section{General Comments}

The functions of the General Comments have also developed in the last decades. Although such Comments were adopted by the HRC already during the Cold War, they were short and mainly of a technical or procedural character. It was only after the end of the Cold War that the Committee started to adopt Comments that contained 'significant normative guidance'. ${ }^{7}$

\footnotetext{
5 Walter Kälin, 'Examination of State Reports' in Keller and Ulfstein (eds), UN Human Rights Treaty Bodies, supra note 3, 16-73 at 36-37.

${ }^{6}$ See the discussion ibid., at 41-71.

${ }^{7}$ Helen Keller and Leena Grover, 'General Comments of the Human Rights Committee and their Legitimacy' in Keller and Ulfstein (eds), UN Human Rights Treaty Bodies, supra note 3, 116-199, at 124.
} 
It is interesting to note that the legal basis for General Comments is not necessarily only the explicit wording of Article 40 of the Covenant. It has also been claimed that their legality may be supported by subsequent state practice since no state has ever protested against the fact that the Committee adopts such Comments - states have even engaged in their drafting. Furthermore, reference is made to the possible 'implied powers' of the Committee, a concept that was accepted by the International Court of Justice with the respect to the United Nations in the Reparations case. ${ }^{8}$

The competence to adopt General Comments is now firmly established. As with the Concluding Observations it is a question about how this competence should be exercised.

First of all, it should be made clear when the treaty body pronounces upon international obligations and when it gives policy advice. Moreover, statements about international obligations should generally be based on the case law of the treaty body, primarily the case law developed on the basis of individual complaints. The reason is that the treaty bodies are hardly mandated nor equipped to adopt general obligations for states, i.e. law-making in its proper sense, without a basis in case law - even if the Comments have a soft law character. In its General Comments, the treaty bodies should furthermore apply a balance between a dynamic interpretation and respect for state consent to the relevant conventions (see section 5 below). As with Concluding Observations, policy advice should be sufficiently connected to the legal obligations. Finally, transparency and involvement of relevant stakeholders should be applied in the adoption of General Comments. ${ }^{9}$

\section{Individual complaints}

The Human Rights Committee's competence to adopt Views in determining individual complaints has a clear legal basis in the (First) Optional Protocol to the ICCPR. ${ }^{10}$ However, there have been divergent opinions as regards the legal status of the Views; the competence to adopt interim measures; as well as the powers to take action to follow-up the implementation of its Views. These issues will be examined in the following. The applicable methods of interpretation will be discussed in section 5 below.

\footnotetext{
${ }^{8}$ Reparation for Injuries Suffered in the Service of the United Nations (Advisory Opinion), ICJ Reports (1949) 174; Keller and Grover, 'General Comments', supra note 7, at 127-128.

${ }^{9}$ See the discussion ibid., at 142-199.

10 Optional Protocol to the International Covenant on Civil and Political Rights, 16 December 1966, entry into force 23 March 1976, 999 UNTS 171, Article 5(4).
} 


\subsection{Views}

Human rights scholarship has accepted that the HRC's Views are not legally binding, but, on the other hand, it is held that states are not free to choose a different interpretation than that of the HRC. ${ }^{11}$ There is a presumption that the HRC's interpretation is correct, and the relevant state must present its counterarguments if it prefers a different interpretation.

HRC stated in its General Comment No. 33 that the Committee's function is not 'as such, that of a judicial body'. ${ }^{12}$ But the Committee said that its Views have 'some important characteristics of a judicial decision'.13 The Views have been adopted 'in a judicial spirit', including 'the impartiality and independence of Committee members, the considered interpretation of the language of the Covenant, and the determinative character of the decisions' ${ }^{14}$ Furthermore, the Committee held that its Views represents 'an authoritative determination' and that states 'must use whatever means lie within their power in order to give effect to the views of the Committee'. ${ }^{15}$ This gives an impression of the Views as tantamount to being legally binding. The draft of the General Comment attracted strong criticism from some states and the General Assembly applied the unusual approach of voting in favour of not 'taking note' of the Comment. ${ }^{16}$

The International Court of Justice expressed its opinion about the legal status of the HRC's decisions in the Diallo case. ${ }^{17}$ The Court held that it was 'in no way obliged, in the exercise of its judicial functions, to model its own interpretation of the Covenant on that of the Committee'. ${ }^{18}$ Furthermore, the ICJ only applied the HRC's practice as support for its own interpretation, which it deemed to be 'fully corroborated by the jurisprudence of the Human Rights Committee'. ${ }^{19}$ But the Court stated that the HRC's practice should be given 'great weight' since the HRC

\footnotetext{
11 See generally about the legal status of Views: Geir Ulfstein, 'Individual Complaints' in Keller and Ulfstein (eds), UN Human Rights Treaty Bodies, supra note 3, 73-116, at 94-100.

12 General Comment No. 33: The Obligations of States Parties under the Optional Protocol to the International Covenant on Civil and Political Rights, UN Doc. CCPR/C/GC/33 (5 November 2008) para 11.

13 Ibid.

14 Ibid.

15 Ibid., paras 13 and 20.

16 UNGA, Resolution on the Report of the Third Committee (A/64/439/Add. 1 and Corr. 1) 64/152. International Covenants on Human Rights, 26 March 2010, UN Doc. A/RES/64/ 152; see International Service for Human Rights, Overview of the 64th Session of the General Assembly, 1, online: www.ishr.ch/general-assembly.

${ }^{17}$ Ahmadou Sadio Diallo (Republic of Guinea v. Democratic Republic of Congo), ICJ Reports (2010-II) 692.

18 Ibid., para. 66.

19 Ibid.
} 
'was established specifically to supervise the application of that treaty'. ${ }^{20}$ The ICJ also referred to the need for promoting 'the necessary clarity', the 'essential consistency' and 'legal security' for both individuals and states. ${ }^{21}$

The HRC has sought - without explicitly saying so - to give the impression that its Views are legally binding. On the one hand, it is not difficult to understand that the Committee may want to strengthen the effects of its Views through an expansive interpretation. This may also increase the political pressure on states parties to implement such Views. On the other hand, the approach of the Committee may be criticized from a strictly legal perspective. Moreover, the Committee may have weakened its own legitimacy, and that of other human rights treaty bodies, by indirectly giving support to sentiments that such organs disregard the requirement of state consent as a basis for international obligations. This may also generate reluctance among states concerning ratification of new human rights conventions and protocols with individual complaints procedures.

It is therefore submitted that, rather than giving the impression that its Views are legally binding, the HRC should concentrate on the scope of the states' obligation to, according to the ICJ, attach 'great weight' to such Views. This may establish a common legal ground for the Committee and states parties, which may also promote the possibilities for actual implementation of the Committee's Views at the national level. Such an approach does not only make good legal sense, but it lays the basis for further refinements of the good faith obligations of states parties. According 'great weight' to the findings of treaty bodies in cases of individual complaints should, as has been referred to above, entail a presumption of the correctness of such findings, and require states parties, including national courts, to present good reasons for any conflicting opinion.

\subsection{Interim measures}

Two questions arise with respect to interim measures: the first is to which extent treaty bodies have the power to adopt such measures and the second is which legal status to be accorded to them. ${ }^{22}$

Neither the Covenant nor the Optional Protocol provides an explicit basis for the adoption of interim measures. There were earlier different opinions about the 'implied powers' of the HRC to adopt interim measures. ${ }^{23}$ But there is an obvious need to prevent execution of a death penalty or expulsion of a person to a country

\footnotetext{
20 Ibid.

21 Ibid.

22 See generally on interim measures: Ulfstein, 'Individual Complaints', supra note 11, at 100-103.

${ }^{23}$ Dominic McGoldrick, The Human Rights Committee: Its Role in the Development of the International Covenant on Civil and Political Rights (Clarendon Press, 1991) at 131.
} 
where she or he might be in danger, before the relevant committee has made its final determination. This should in itself suffice to demonstrate the competence of these committees to adopt interim measures. Subsequent human rights treaties, such as the Optional Protocol to the Convention on the Elimination of All Forms of Discrimination against Women (CEDAW), have included an express basis for adopting interim measures. ${ }^{24}$

However, implied powers would not necessarily determine the legal status of such measures. There have been different opinions in legal scholarship on whether such measures are legally binding. In recent years, several international courts and treaty bodies have clarified their position as to the legal status of interim measures, and they have all concluded that such measures are legally binding. For example, the Human Rights Committee established in its General Comment No. 33 that its interim or provisional measures are legally binding: 'Failure to implement such interim or provisional measures is incompatible with the obligation to respect in good faith the procedure of individual communication established under the Optional Protocol.'25

In relation to international courts it may be argued that, since they can issue binding final judgments, they should also have the competence to adopt binding interim measures. States parties have accepted that these courts should be delegated powers to adopt judgments in order to fulfill the objectives of the treaty, and they have a composition and procedures to exercise such powers in a way states find trustworthy. It can be argued that, when international courts can make final binding decisions, they should a fortiori have the competence to impose the temporary restrictions on states represented through binding interim measures.

No such inference from the binding status of the final decisions may be drawn in the case of treaty bodies. It is, however, equally relevant for treaty bodies, in their function of receiving individual Communications, that they were established in order to protect individual human rights. If states were free to disregard interim measures in cases where it would result in irreparable harm, such as execution of a death penalty or expulsion to torture in another state, the objective of the treaty bodies would not be fulfilled, since the subsequent finding of the treaty body in the relevant case would have no possibility of influencing the decision of the state, much less of being accorded 'great weight'. Furthermore, interim measures are by nature of a temporary and not final character.

\footnotetext{
${ }^{24}$ Optional Protocol to the Convention on the Elimination of All Forms of Discrimination against Women, GA Res 54/4, 6 October 1999, entry into force 22 December 2000, 2131 UNTS 83, Article $5(1)$.

${ }^{25}$ General Comment No 33, supra note 12, para 19.
} 
While acknowledging the absence of an explicit basis in the treaties for binding interim measures, it should be sufficient for accepting their binding character that such a legal status is necessary in order to fulfill what was intended by the individual complaints procedures, i.e. the protection of the individual through findings by the relevant treaty body. Thus, as argued by Christian Tomuschat, an effective interpretation (effet utile) should be applied. ${ }^{26}$

\subsection{Follow-up measures}

The legal power of the treaty bodies to address non-compliance by states parties has also been an issue of controversy. In their submissions to the on-going treaty body strengthening process, China has for example stated that '[f]ollow-up procedures should not burden the States parties with extraneous obligations', while Russia has said that '[f]ollow-up procedures have been developed by treaty bodies and are not covered by international treaties. Thus, States parties are under no obligation to work with committees on follow-up procedures' ${ }^{27}$

The decision to publish the Views of the HRC was taken without any express basis in the First Optional Protocol. ${ }^{28}$ A consensus was gradually developed that followup procedures could be based on the HRC's implied powers. ${ }^{29}$ This is plausible, given the need for effective implementation of the treaty obligations. The Optional Protocol to CEDAW is an example of a more recent treaty explicitly providing for an obligation for states parties to report on their follow-up on findings by the CEDAW Committee. ${ }^{30}$ However, the treaty bodies have no powers to put pressure on non-complying states - except for 'naming and shaming'.

\section{Methods of interpretation}

The treaty bodies are bound to interpret the obligations of states parties as set out in the human rights conventions, but the ambit of these obligations may be extended through effective and dynamic interpretation. Such interpretation techniques are commonly used by the treaty bodies.

\footnotetext{
${ }^{26}$ Christian Tomuschat, Human Rights: Between Idealism and Realism (2nd edn, Oxford University Press, 2008) at 218.

27 See 'The Treaty Body Strengthening Process: Individual Submissions by States Parties', $<$ www2.ohchr.org/english/bodies/HRTD/StakeholdersContextConsultations.htm $\geq$.

28 Torkel Opsahl, 'The Human Rights Committee' in Philip Alston (ed), The United Nations and Human Rights: A Critical Appraisal (2nd edn, Clarendon Press, 2002) 369-444 at 421.
}

${ }^{29}$ Alfred de Zayas, 'Petitions before the United Nations Treaty Bodies: Focus on the Human Right Committee's Optional Protocol Procedure' in Gudmundur Alfredsson et al. (eds), International Human Rights Monitoring Mechanisms: Essays in Honour of Jacob Th. Möller (Martinus Nijhoff, 2009) 35-77 at 75. See also Markus Schmidt, 'Follow-up Activities by UN Human Rights Treaty Bodies and Special Procedures Mechanisms of the Human Rights Council: Recent Developments', ibid., 25-35 at 26.

30 Optional Protocol to CEDAW, supra note 24, Article 7(4). 
The treaty bodies have been criticized for an excessively expansive interpretation. $^{31}$ It is difficult to see that the treaty bodies generally apply interpretation methods deviating from the methods used in other parts of international law. ${ }^{32}$ But writers have pointed to examples where the treaty bodies allegedly may have gone too far in their interpretation. Kerstin Mechlem refers to General Comments adopted by the Committee on Economic, Social and Cultural Rights (CESCR) on the obligations of international organisations, states' extraterritorial obligations and the concept of 'core obligations'. ${ }^{33}$ Urfan Khaliq and Robin Churchill speak of the CESCR's 'quasi-legislative approach to certain issues, notably the rights to adequate housing and water' and that the HRC with regard to the right to life has adopted 'an extremely expansive approach, one that encompasses, inter alia, housing, health and nutrition'. ${ }^{34}$

The expansion of treaty obligations through an effective or dynamic interpretation is a double-edged sword to the extent that states may argue that the treaty bodies do not respect traditional canons of treaty interpretation, and thus engages in lawmaking beyond their mandate as supervisory bodies. Such opinions may prevent implementation of the treaty bodies' findings in domestic law. But they may also prevent the necessary political and financial support by states in the current treaty body strengthening process. It is therefore of importance that the treaty bodies balance the need for effective human rights protection through their interpretation while respecting accepted methods of treaty interpretation.

\section{Conclusions}

The treaty bodies have been very successful in clarifying and developing their role as supervisory organs, especially after the end of the Cold War. But this expansion has led to two difficulties: criticism of going too far in both their legal and policy functions, and reaching - and over-reaching - their capacity to dealing with state reports and individual complaints, resulting in increasing backlogs.

It would seem advisable that the treaty bodies took note of both these restraints. They should ensure effective human rights protection, but only as far as their mandate allows. Hence, they should engage in law-making only to the extent allowed by accepted principles of treaty interpretation. Furthermore, the policy advice should not be at the expense of the treaty bodies' core legal functions. The

\footnotetext{
31 Kerstin Mechlem, 'Treaty Bodies and the Interpretation of Human Rights', 42 Vanderbilt Journal of Transnational Law (2009) 905-947 at 908.

32 Birgit Schlütter, 'Aspects of Human Rights Interpretation by the UN Treaty Bodies' in Keller and Ulfstein (eds), UN Human Rights Treaty Bodies, supra note 3, 261-320 at 317.

33 Mechlem, 'Treaty Bodies', supra note 31, at 931, 935 and 940.

34 Urfan Khaliq and Robin Churchill, 'The Protection of Economic and Social Rights: A Particular Challenge?' in Keller and Ulfstein (eds), UN Human Rights Treaty Bodies, supra note 3, 199-260 at 260.
} 
shortage of resources in the UN system may also have the effect of requiring more prioritizing in exercising the treaty bodies' different functions. But that is another story. 